\title{
Acanthochelys pallidipectoris (Freiberg 1945) - Chaco Side-Necked Turtle
}

\author{
Thomas Vinke ${ }^{1}$, Sabine Vinke ${ }^{1}$, Enrique Richard ${ }^{2}$, Mario R. Cabrera ${ }^{3}$, \\ Lorena Paszko ${ }^{4}$, Pablo Marano $^{5}$, and Sébastien Métrailler ${ }^{6}$ \\ ${ }^{1}$ Filadelfia 853,9300 Fernheim, Paraguay [s-t-vinke@gmx.de]; \\ ${ }^{2}$ Cnl Valdéz 1327, Villa Pabón, La Paz, Bolivia [chelonos@gmail.com]; \\ ${ }^{3}$ Depto. Diversidad Biologica y Ecologia, Universidad Nacional de Cordoba, \\ Velez Sarsfield 299,(5000) Cordoba, Argentina [mcabrera@efn.uncor.edu]; \\ ${ }^{4}$ Delegación Regional NEA, Administración de Parques Nacionales, \\ Belgrano 997, Mburucuyá, Corrientes, Argentina [lorena_paszko@yahoo.com.ar]; \\ ${ }^{5}$ Mansilla 2724 piso 8, 1425 Ciudad Autonoma de Buenos Aires, Argentina [pablo_marano@hotmail.com]; \\ ${ }^{6}$ Chemindu Bosquet 6, 1967 Bramois, Switzerland [s.metrailler@bluewin.ch]
}

Summary. - The Chaco Side-necked Turtle, Acanthochelys pallidipectoris (Family Chelidae), is a small to medium-sized freshwater turtle (carapace length to ca. $180 \mathrm{~mm}$ ), endemic to the Chaco ecoregion of Argentina, Bolivia, and Paraguay. Its distribution is restricted to the temporarily flooded marshes and lowlands of dry shrub forest with impenetrable soils. The only record outside of the dry Chaco, in Mendoza, Argentina, is likely of anthropogenic origin. The activity period is very short (4-6 months a year), and populations consist of few animals. The species is threatened by habitat loss combined with climatic change leading to increased aridity and diminished ephemeral water resources. The species is currently categorized as Vulnerable on the IUCN Red List based on a 1996 evaluation, but has recently been provisionally re-assessed as Endangered.

Distribution. - Argentina, Bolivia, Paraguay. Endemic to the Chaco ecoregion of southern Bolivia, western Paraguay, and northern Argentina.

SynONYMy. - Platemys pallidipectoris Freiberg 1945, Acanthochelys pallidipectoris.

SuBSPECIES. - None currently recognized.

STATUS. - IUCN 2011 Red List: Vulnerable (VUA1c, D1) (assessed 1996, needs updating); TFTSG Draft 2011: Endangered; CITES: Not Listed.

Taxonomy. - This species was described as Platemys pallidipectoris by Freiberg (1945) based on a female specimen from Presidencia Roque Sáenz Peña, of Chaco Province, Argentina (26 $\left.48^{\prime} \mathrm{S}, 60^{\circ} 26^{\prime} \mathrm{W}\right)$. The holotype was collected by Augusto V.Aula in 1944 and donated to Marcos A. Freiberg who deposited it in the collections of the Museo Argentino de Ciencias Naturales Bernardino Rivadavia in Buenos Aires (MACN 1731).
In a karyological study, McBee et al. (1985) demonstrated that Platemys platycephala warranted monotypic status and that P.macrocephala, $P$.radiolata, $P$. spixii, and $P$. pallidipectoris represented a separate monophyletic lineage. Rhodin (1985) noted the availability of the generic name Acanthochelys Gray 1873 for this monophyletic group, and Iverson (1986) formalized this designation for the species as Acanthochelys pallidipectoris.

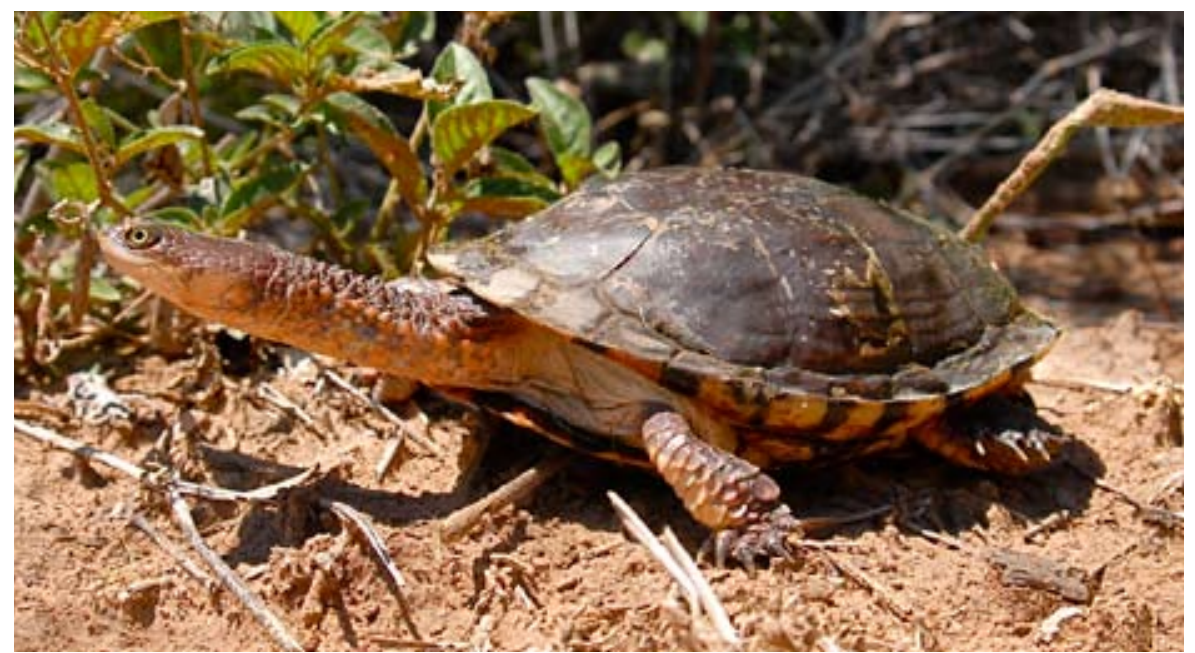

Figure 1. Adult female Acanthochelys pallidipectoris from Boquerón, Paraguay. Photo by Thomas and Sabine Vinke. 

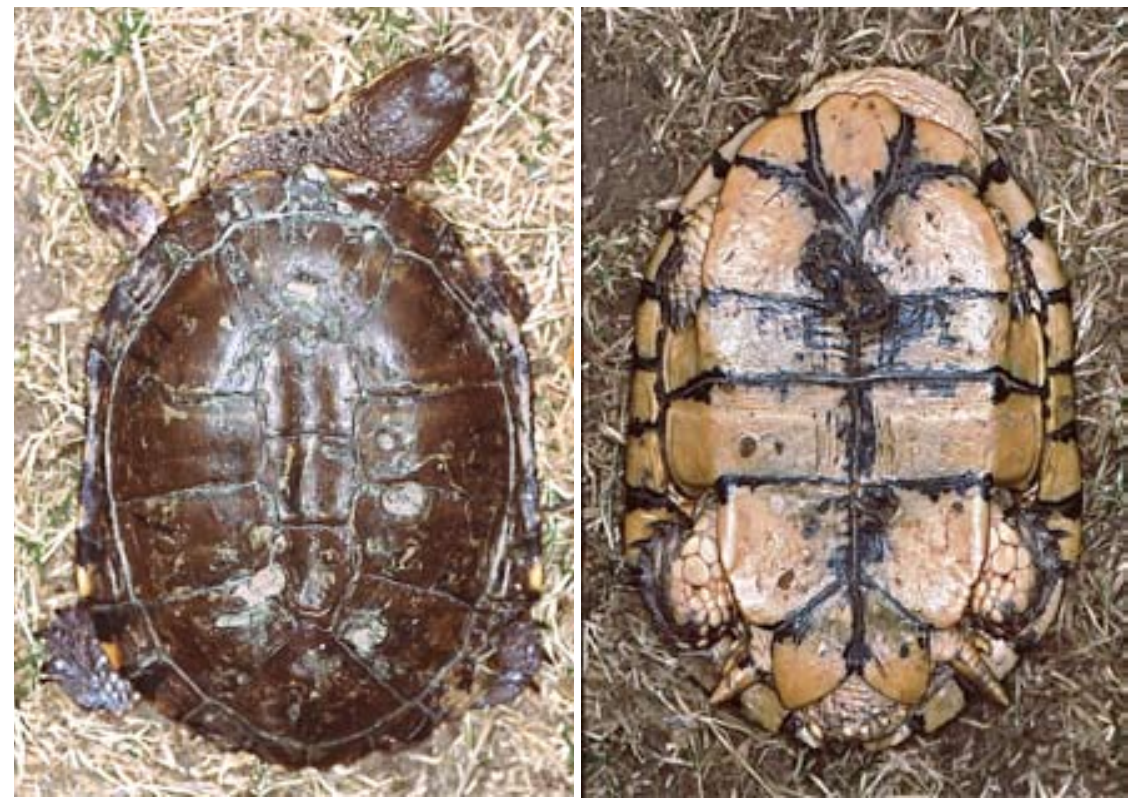

Figure 2. Adult male Acanthochelys pallidipectoris $(\mathrm{CL}=180 \mathrm{~mm})$ from Salta, Argentina; note the large horny ischial spurs. Photos by Sebastien Métrailler.

Description. - Acanthochelys pallidipectoris is a medium-sized turtle, with maximum recorded adult size 180 mm carapace length $(\mathrm{CL})$ for a male (Métrailler, pers. obs.), and $175 \mathrm{~mm}$ CL for a female (Freiberg 1945). Monguillot and Fabius (1993) described 13 adult males between 128 and $150 \mathrm{~mm} \mathrm{CL}$, and 11 adult females between 135-156 mm CL. Paszko and Hernando (2005) recorded females of sizes between 133-162 mm and males of 134-150 mm CL. In Salta Province, Argentina, Métrailler observed the following average sizes for the shell: $161 \mathrm{~mm} \mathrm{CL}$ and 127 mm carapace width $(n=6$, maximum $=170 \mathrm{~mm})$ in females and 162 by $124 \mathrm{~mm}(\mathrm{n}=8$, maximum $=180 \mathrm{~mm})$ in males (Métrailler, pers. obs.). The weight of a fully-grown adult is around $400 \mathrm{~g}$ (Richard and Bertonatti 1998).

The carapace is elliptical, broader posteriorly, and widest across marginals 8 (Cabrera 1998). The nuchal scute is present, 1.5-2 times longer than broad. A shallow dorsal groove occurs between the first and fifth vertebral scutes. There are 12 supracaudal scutes, the first slightly broader than long, and marginals 4-7 are recurved. Neural bones are completely absent.

Carapacial coloration is highly variable, from light or dark brown to brownish-green, and some animals have a

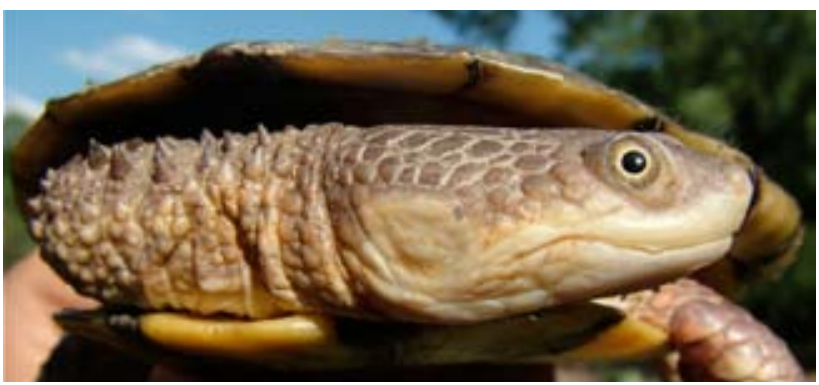

Figure 3. Acanthochelys pallidipectoris from Campo Loa, Boquerón, Paraguay. Photo by Thomas and Sabine Vinke. black carapace (Monguillot and Fabius 1993). If the color is a very light brown, sometimes the underlying sutures of the bones are visible through the nearly transparent scutes (Monguillot and Fabius 1993).

The plastron is broader posteriorly and has a large intergular. The length and proportions of the plastral seams are highly variable, i.e., in the holotype the pectoral seam is the shortest and the femoral seam the longest (Freiberg 1945); however, Cabrera (1998) depicts a specimen in which the humeral is the shortest and the anal the longest. The background plastral coloration is ivory yellow, with black along the seams of the plastral scutes. The dark borderings may be highly extended, causing the plastron to be nearly totally black. In young turtles the base plastral color is orange (Cabrera 1998).

The brownish head is longer than broad, covered with polygonal scutes of irregular size increasing towards the neck. The nares and eyes are prominent, with the color of the iris a brilliant yellow. Two small chin barbels are
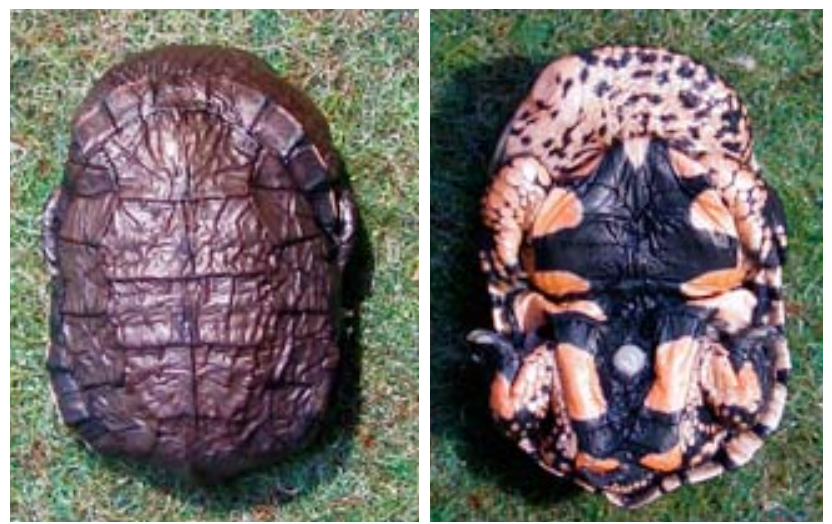

Figure 4. Hatchling Acanthochelys pallidipectoris from Salta, Argentina. Photos by Sebastien Métrailler. 


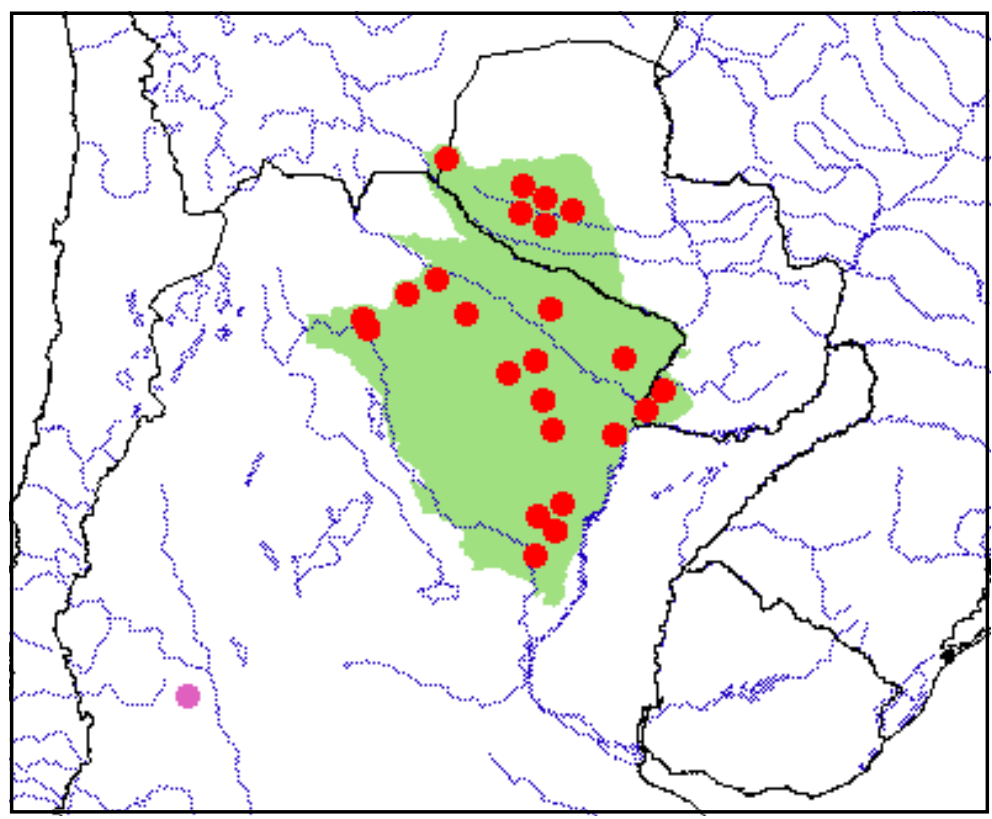

Figure 5. Distribution of Acanthochelys pallidipectoris in southern Bolivia, western Paraguay, and northern Argentina in central South America. Red dots = museum and literature occurrence records of native populations based on Iverson (1992), plus more recent and authors' data; purple dot $=$ introduced population; green shading $=$ projected native distribution based on GIS-defined hydrologic unit compartments (HUCs) constructed around verified localities and then adding HUCs that connect known point localities in the same watershed or physiographic region, and similar habitats and elevations as verified HUCs (Buhlmann et al. 2009), and adjusted based on authors' data.

present. The length of the head and neck measure about $2 / 3$ of the CL (Richard 1999). The dorsum and sides of the neck bear relatively prominent conical tubercles. The coloration of the head and extremities is brownish, and the face is white, yellowish, or rosy. In some specimens the tubercles of the neck are red or pinkish. Specimens of a more eastern origin (probably from the Province of Santa $\mathrm{Fe}$ ) show a more reddish, burgundy coloration of the head and neck (Marano, pers. obs.) in comparison to specimens from the western Chaco, which are more of a brownishyellow tone.

The legs are short and robust, and the feet are webbed, with toes having relatively large and sharp claws. One to three large horny ischial spurs are present on the hind extremities, measuring up to $15 \mathrm{~mm}$ (Cei 1993) or $20 \mathrm{~mm}$ (Richard 1999) in height, and may be straight or curved (Cabrera 1998). The length of the spurs is highly variable and does not depend on the size of the individual; i.e., the largest male $(180 \mathrm{~mm}$ CL) found in Salta Province, Argentina, had spurs of $18 \mathrm{~mm}$, a small female of $155 \mathrm{~mm}$ CL had spurs of $14 \mathrm{~mm}$, and the spurs of the largest female (170 mm CL) measured only 3 $\mathrm{mm}$ (Métrailler, pers. obs.).

Monguillot and Fabius (1993) did not note any sexual dimorphism in size, coloration, or spurs of A. pallidipectoris. However, Richard (1998) and Paszko and Hernando (2005) recorded that females are slightly larger than males, and Paszko and Hernando (2005) observed that of the three pairs of horny tubercles in males, the first or second pair was enlarged, whereas in females there was a tendency for the second and in some cases the third pair to be bigger than the others, although this was not as clearly developed as in males. Sexual dimorphism occurs in form and size of the plastron, which is concave in adult males, with a deeper anal notch and longer tail than in females (Cabrera 1998).

In three specimens of A.pallidipectoris bred in captivity the shell of hatchlings had an average size of 31 by $21 \mathrm{~mm}$, and the carapace and top of the head, neck, and limbs were evenly grayish brown, reminiscent of the clay soil of the natural habitat. The plastron and the underside of the head, neck, and limbs were yellowish orange with small grayish brown spots; the center of the carapace was greyish brown with large orange-yellow spots on the marginals, with the undersides of the marginals yellow or orange (Métrailler, pers. obs.). Giambelluca (1988) recorded the carapace size of a supposedly very small A. pallidipectoris hatchling as being only 14.8 by $11.9 \mathrm{~mm}$, but the specimen was actually a misidentified A. spixii (Giambelluca, pers. comm.).

Distribution. - Acanthochelys pallidipectoris is distributed in the plains of the Chaco ecoregion of western Paraguay (Boquerón, Neembucu, Presidente Hayes), southern Bolivia (Tarija), and northern Argentina (El Chaco, Formosa, Salta, Santa Fe, Santiago de Estero). The only record outside of the Chaco, in Mendoza, Argentina, is most likely of anthropogenic origin (Richard 1994).

The figured distribution map was based on the following primary sources: Saporiti 1943; Freiberg 1945; Fernández 1987; Buskirk 1988; Waller 1988; Richard 1991; Monguillot and Fabius 1993; Lavilla et al. 1995; Giraudo 1996; Cabrera 1998; Piña and Larriera 2001; Vinke and Vinke 2001, 2008; Scrocchi and Giraudo 2001; Paszko and Hernando 2005; Gonzales et al. 2006; Zarco and Quiroga 2008; Álvarez et al. 2009. Fritz and Pauler (1992) mentioned the first finding in 

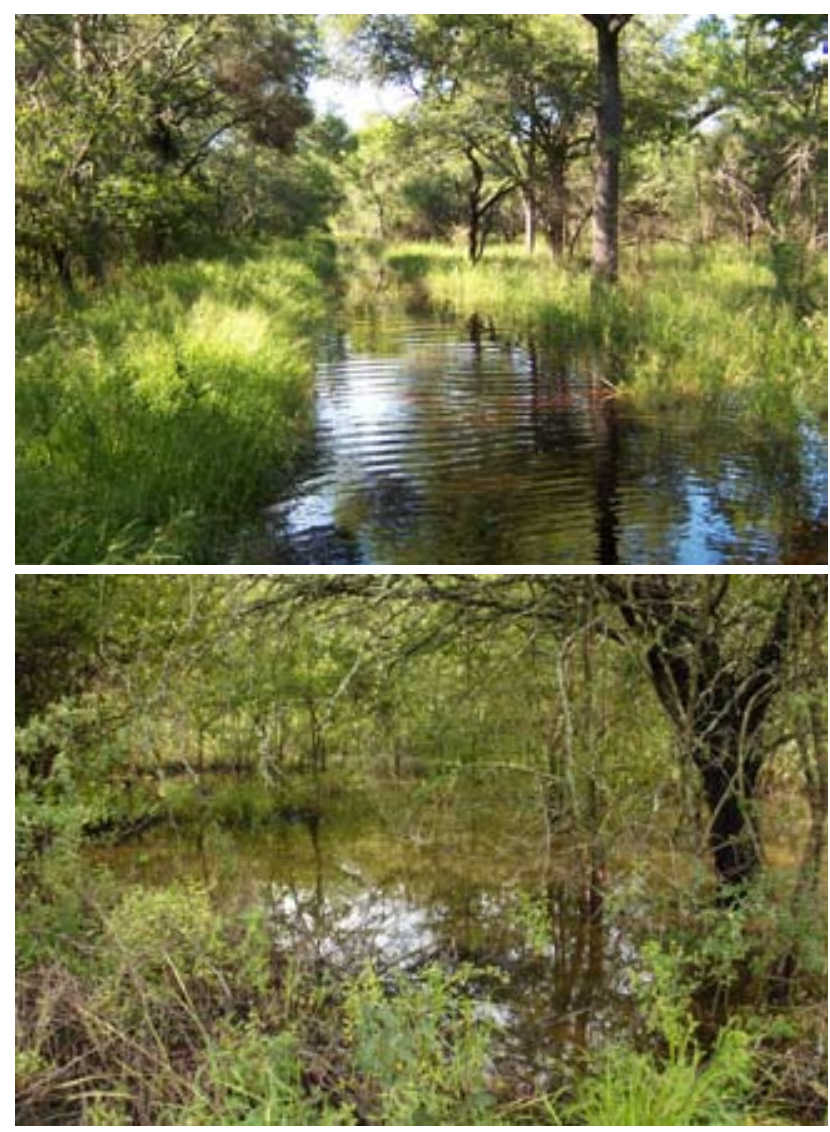

Figure 6. Habitat of Acanthochelys pallidipectoris. Top: Chaco National Park, El Chaco,Argentina.Photo by Lorena Paszko. Bottom: Typical lowland temporarily inundated habitat in the Chaco, Boquerón, Paraguay. Photo by Thomas and Sabine Vinke.

Paraguay, but the cited location "surrounding of Filadelfia" does not seem appropriate, as the animals had been bought by indigenous dealers and Filadelfia appears to be out of the range (Vinke and Vinke 2008).

Habitat and Ecology. - Acanthochelys pallidipectoris is restricted to the temporarily flooded marshes and lowlands of the Gran Chaco, characterized by dry shrub forest with impenetrable soils. The species is broadly sympatric with the Scorpion Mud Turtle, Kinosternon scorpioides, and the Chaco Tortoise, Geochelone petersi, but not with the Bigheaded Pantanal Swamp Turtle,A.macrocephala (Vinke and Vinke 2009); it is also microsympatric with K. scorpioides (Vinke and Vinke, pers. obs.).

The species is both diurnal and nocturnal, and its active period is restricted to the warmer rainy season (less than 6 months, sometimes only 4 months), between October and March. The species apparently estivates primarily on land during the cooler dry season from April to September. In the National Park Chaco (Argentina) animals leave waterbodies when temperatures are below $20^{\circ} \mathrm{C}$ and seek shelter under Bromelia and Aechma spp. (Paszko and Hernando 2005). In Mendoza, Argentina, they estivate under bushes of Canna sp. and have been found ca. $5 \mathrm{~cm}$ under the soil under the trunk of a Salix sp. tree (Richard 1999). Temperatures in the soil at hibernation sites have been recorded as low as $2-5^{\circ} \mathrm{C}$ (Richard 1999).
The reproductive period occurs during the short rainy season during the summer (January through March). All adult females encountered by Monguillot and Fabius (1993) were gravid in January. Mating has been recorded on land (Paszko and Hernando 2005; Gonzales et al. 2006). Both males and females appear to become sexually mature at about 130-140 mm CL and 325-400 g (Horne 1993). Apparently a single clutch of 2-5 eggs is produced per year (Richard 1991; Horne 1993). The eggs are hard-shelled, white, and longer than wide (Cabrera 2009). The only reported breeding success in captivity needed 399 days of incubation, and after that the eggs were opened manually. The incubation period consisted of three phases: 50 days with variable day and night temperatures of $15-24^{\circ} \mathrm{C}$, followed by 178 days at a constant $10^{\circ} \mathrm{C}$, and 171 days at $29^{\circ} \mathrm{C}$. Hatchlings measured 31 by $21 \mathrm{~mm}$ (Métrailler 2008), the same as naturally hatched specimens (Paszko and Hernando 2005). There is no information about sex ratios in wild populations.

Acanthochelys pallidipectoris shares its natural habitat with a large diversity of amphibians and fishes (e.g., killifish). However, when turtles emerge from estivation the waterbodies do not contain sufficient animals for nutrition, since they have been dried out, so at first turtles feed primarily by neustophagia (skimming and filtering microorganisms from the surface of the water) (Richard 1999). Later in the season, Richard (1999) observed A. pallidipectoris in Mendoza that fed on insects (64\%, 9 species), amphibians (14\%, 8 species), spiders ( $7 \%, 1$ species), fish ( $7 \%, 1$ species), and by neustophagia $(1 \%)$.

In two years of captivity, a female fed only on tadpoles, small fishes $(1-2 \mathrm{~cm})$, and small pieces of meat, although other different types of food were also provided (Richard 1999). The holotype which was kept in the collection of Freiberg (1947) fed on meat in the water. Specimens in captivity have fed on meat of fish, tubifex, bloodworms, and earthworms (Mertens 1954), or on meat, fish, shrimp, insects, and small aquatic snails, apparently avoiding vegetables (Métrailler, pers. obs.).

At Castelli, in the Argentine Chaco, a specimen of $A$. pallidipectoris was found with an unidentified tick that survived 2 weeks in the water until it was removed manually (Marano, pers. obs.).

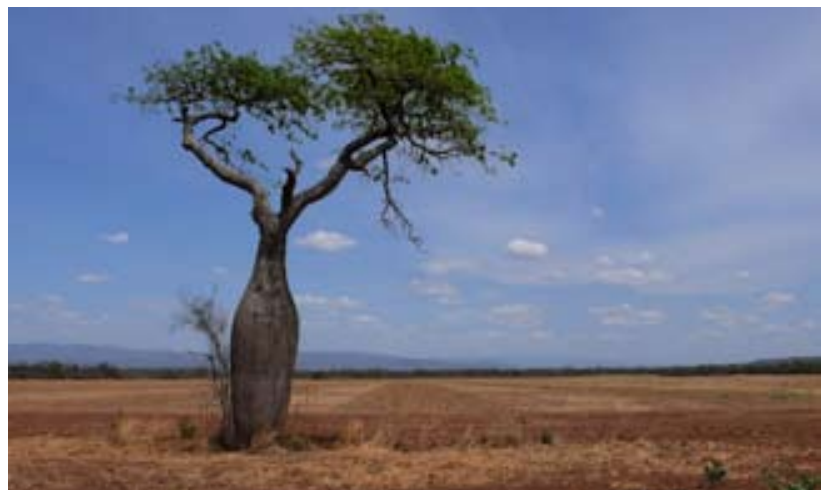

Figure 7. Massive clearing for soybean production in Dpto. de Orán, Salta, Argentina, in an area that was previously habitat for A. pallidipectoris. Photo by Enrique Richard. 
Population Status. - Acanthochelys pallidipectoris apparently occurs in extremely small populations (Richard 1999; Vinke, pers. obs.). Even after heavy rains, they are not locally abundant. No more than three specimens were discovered in an area of about $10 \mathrm{~km}^{2}$, even under extremely favorable conditions, such as the first heavy rain in spring (Vinke, pers. obs.). The largest known single population was observed in National Park Chaco, ElChaco, Argentina, where 21 specimens were found in a range of 13 ha, inhabiting a dense net of shallow, ephemeral artificial and natural ponds (Paszko and Hernando 2005). In two additional locations outside the main occurrence of this population, but within the protected area, residents maintaining low-impact cattle farms considered the species as common (Paszko, unpubl. data).

In Salta, Argentina, Métrailler (unpubl. data) observed a large concentration of A. pallidipectoris in an artificial water pond in January after two days of rain. In this biotope of $30 \mathrm{~m}^{2}$ and a maximum depth of $1 \mathrm{~m}$, used to store water for livestock, he captured 16 individuals (14 adults and 2 subadults). He noted a very high density of tadpoles present in the pond, and there were also aquatic insects, but no fish or other turtle species.

Threats to Survival. - The Paraguayan Chaco is considered among the most important wilderness ecoregions in the world, but with a high rate of habitat loss for ranching development, especially extensive cattle grazing. In 2009, after a public discussion in Paraguay concerning a possible future zero-clearing act, the allowable clearing rate was instead raised from 500 ha/day to 1500 ha/day (Wilfried Giesbrecht, pers. comm.; Vinke and Vinke 2009).

In contrast to its congener, A. macrocephala, a species that seems to be adapting to the altered landscape by opportunistically utilizing artificial cattle ponds (Vinke and Vinke 2001, 2008; Rhodin et al. 2009), this development of increased habitat destruction severely threatens A. pallidipectoris. As described above, this species is restricted to the temporarily flooded marshes and lowlands of the dry shrub forest with impenetrable soils. In the western Chaco this type of soil is restricted to stream beds (cauces). These are not rivers in a strict sense, they flow only in parts and only for some days every few years, but after heavy rains the waters build a network of separate flooded areas within the river bed. For cattle farmers, the clay consistency of the soil in these river beds is of extremely high value and therefore this habitat type is widely destroyed by either digging it out as deep water reservoirs for cattle, or by removing the soil to build high tanks for the same function. This action destroys habitat for A. pallidipectoris.

In addition, in Paraguay, competition with A. macrocephala and the black caiman, Caiman yacare, which have both migrated into the dry Chaco following the habitat modified by cattle farming, are apparent threats where more water is available (Vinke and Vinke 2008).

Finally, data suggest that changing climate regimes causing drought and abnormally low temperatures in winter and extremely high temperatures in spring and summer are likely to become an increasing threat in the future with gradually increasing aridity and possible desertification of the landscape (e.g., the 2007 winter was the coldest on record in South America, and the drought in 2008-2009 lasted 16 months in the Chaco (Vinke and Vinke, pers. obs.).

In Argentina the predominant threat is extensive habitat loss caused by intensive monoculture of soybean, especially in the provinces of Chaco, Formosa, Santiago del Estero, northwestern Santa Fe, and northeastern Salta. This monoculture is seriously impacting the stability of the entire Chaco ecosystem, and therefore also the populations of A.pallidipectoris, which are only found in the few isolated remains of the native Chaco vegetation. Between the years 2002 and 2006, an area of 660,000 ha of natural Chaco forest was cleared for new soybean cultivation and 160 million liters of the herbicide glyphosphate (Round$\mathrm{Up}^{\circledR}$, Monsanto Co.) was used, without any investigation of its impact on the soil or the fauna and flora (Picoloti 2010). A journey through the region of the Chaco in Salta in 2009 showed the huge devastation (Richard, pers. obs.), leaving the fauna, including A. pallidipectoris, without any habitat. Without a doubt the indiscriminate use of herbicides such as glyphosphate has a strong impact on the survival of the biodiversity of the region.

Cattle farming in Argentina has also impacted $A$. pallidipectoris habitat. Although small-scale traditional farming is not a major risk for the species, large-scale industrial cattle farming with overgrazing and overexploitation of the forest for lumber are major risk factors for conservation of the species (Paszko, pers. obs.).

In Salta Province, Argentina, some indigenous peoples think that A.pallidipectoris is poisonous, believing that the spurs located on the hind legs are poisonous needles. They seem to be even more wary of juveniles with their vivid plastral coloration. Several families interviewed said that if they find hatching A. pallidipectoris they kill them by crushing them (Métrailler, pers. obs.). The species is also used in the Umbanda cult, a widespread spiritual AfroBrazilian religion with adherents in the region; a hind foot of A. pallidipectoris is hung up to dry as a cure for asthma (Marano, pers. obs.).

In the Chaco of Bolivia, the Ayorean ethnic group uses A. pallidipectoris as rattles and amulets in their traditional practices (Richard, pers. obs.). They use the carapace of juvenile A.pallidipectoris as a rattle, putting a stick of palo santo or vera tree (Bulnesia sarmientoi) into the opening as a clapper, which makes a noise when striking the inner surface of the carapace. The Ayoreo hang these rattles from their belts when leaving for hunting and when walking they emit a special sound. When they need to communicate during the hunt they shake the rattle like a bell, with different rhythms interpreted by other Ayoreo as a code, allowing the possibility of some communication between different members of the tribe. The Ayoreo also believe that carrying parts of a turtle or tortoise (usually the Chaco Tortoise, Chelonoidis petersi or A.pallidipectoris) in their chuspa (a shoulder bag made 
of fibers of chaguar = wild Bromelia sp. or Aechmea sp.) provides the hunter with the silence and discreteness of a tortoise (Ayoreo hunters, Chaco Boreal, Paraguay, 1999, pers. comm. to Richard). Hispanic settlers in the Chaco area also use turtle and tortoise carapaces, including $A$. pallidipectoris, to make charangos, a typical regional musical instrument (Richard, pers. obs.).

For Argentina, a high level of trade has been described, at least in the late 1990s (Richard 1998; Chebez 1999; Chebez et al. 2008). Commerce in Paraguay is illegal, but sometimes observed (Fritz and Pauler 1992; Vinke and Vinke, pers. obs.). Probably the species is not currently traded from Bolivia because of its marginal occurrence and relatively inaccessible habitat. But browsing the pet trade market on the internet shows that $A$.pallidipectoris is always available in Europe and USA, indicating that there must be trade from the countries of origin.

Conservation Measures Taken. - Acanthochelys pallidipectoris has protected status in Paraguay and Argentina and the only known occurrence of the species in Bolivia is in a National Reserve (El Corbalán, Tarija). However, the protection is not apparently effective, because specimens are continuously available in the international pet trade. The species is not known to occur in any National Park in Paraguay (Vinke and Vinke 2008) and the large El Chaco Biosphere Reserve (4,554,909 ha) in the Paraguayan Chaco recently created is completely situated in the northern Chaco, outside the range of A. pallidipectoris. In Argentina, the species has been reported from the Chaco National Park (Cabrera 1998; Paszko and Hernando 2005). Research on trends in population numbers, and the enforcement of current protected status are required.

The species is currently categorized as Vulnerable on the 2011 IUCN Red List (www.iucnredlist.org), but that assessment is from 1996 and needs updating. Recently, at the IUCN/TFTSG South American Turtle and Tortoise Red List Workshop, Rio Trombetas, Brazil, 10-14 October 2010, the populations in Argentina and Bolivia were provisionally assessed as Endangered (Richard 2010, unpubl. data), as were those in Paraguay (Vinke and Vinke 2010, unpubl.data). The recently finished Recategorización de la Herpetofauna Argentina lists this species as "Amenazada" (Threatened) (M. Cabrera and E. Richard, pers. comm.). Final re-assessment for an official updated IUCN Red List status is currently being undertaken by the TFTSG and IUCN (A.G.J. Rhodin and P.P. van Dijk, pers. comm.), and at this time it appears the species should be listed as Endangered.

Conservation Measures Proposed. - Research into population numbers and trends, and status of habitat should be undertaken. Basic natural history, demographic, and ecological studies are also needed. Monitoring of the international pet trade needs to be continued, and any indication of unsustainable take investigated. The identification and periodic monitoring of key indicator populations in the Chaco ecoregion needs to be initiated, especially those within protected areas. Ensuring the protection of critical habitat for the species is important in the face of rampant developmental destruction of its specialized Chaco habitat.

Captive Husbandry. - Captive breeding of A.pallidipectoris requires specific climatic parameters and large aquatic and terrestrial surfaces. Depending on the time of the year, turtles live in the water or on land where they burrow into the soil. Reproduction is difficult due to these restraints that are particularly important during the incubation of eggs. There are currently no captive breeding programs for $A$. pallidipectoris. Captive breeding of this species instead of in-situ conservation is not an effective solution.

Current Research. - None known.

Acknowledgments. - We thank Anders Rhodin and John Iverson for review comments and language editing.

\section{LITERATURE CITED}

Álvarez, B.B., Ruiz García, L.A., Céspedez, J.A., Hernando, A.B., Zaracho, V.H., Calamante, C.C., and Aguirre, R.H. 2009. Herpetofauna, provinces of Chaco andFormosa, Chaco Oriental region, north-eastern Argentina. Check List 5(1):74-82.

Buhlmann, K.A., Akre, T.S.B., Iverson, J.B., Karapatakis, D., MitTermeier, R.A., Georges,A., Rhodin,A.G.J., vAN DiJk, P.P., AND GibBons, J.W. 2009. A global analysis of tortoise and freshwater turtle distributions with identification of priority conservation areas. Chelonian Conservation and Biology 8(2):116-149.

BUSKIRK, J.R. 1988. New locality records in Argentina and Paraguay for the chelid turtles Platemys pallidipectoris (Freiberg) and Platemys macrocephala (Rhodin et al.). Herpetological Review 19(4):74-75.

CABRERA,M.R.1998.Lastortugascontinentales deSudamérica austral. Córdoba, Argentina: Privately printed, $120 \mathrm{pp}$.

CABrera, M.R. 2009. Las tortugas argentinas. In: Montero, R. and Autino, A. (Eds.). Sistemática y Filogenia de los Vertebrados, con Énfasis en la Fauna Argentina. Tucumán, pp. 183-188.

CEI, J.M. 1993. Reptiles del noroeste, nordeste y este de la Argentina: herpetofauna de las selvas subtropicales, Puna y Pampas. Museo Regionale di Scienze Naturali Monografie (Turin) 4:1-527.

CHEBEZ, J.C. 1999. Los que se van: especies argentinas en peligro. Buenos Aires: Editorial Albatros, pp. 85-87.

Chebez, J.C., Paszko, L., Waller, T., And Richard, E. 2008. Tortuga canaleta chaqueña, Acanthochelys pallidipectoris (FrEIBERG 1945). In: Chebez, J.C. (Ed.). Los Que Se Van. Tomo I. Buenos Aires: Editorial Albatros, pp. 236-239.

FERNÁNDEZ, M.S. 1987. Ampliación de la distribución geográfica de Platemyspallidipectoris Freiberg, 1945(Chelonii:Chelidae).Boletín de la Asociación Herpetológica Argentina 3(1-2):9.

FREIBERG,M.A. 1945.Unanuevaespecie de tortugadel género Platemys Wagler. Physis 20(55):19-23.

FREIBERG, M.A. 1947.El alotipo de la tortuga Platemys pallidipectoris Freiberg. Physis 20(56):112-114.

Fritz, U. AND PAULER, I. 1992. Erstnachweis von Acanthochelys pallidipectoris (Freiberg, 1945) für Paraguay (Testudines: Pleurodira: Chelidae). Herpetozoa, Wien 5(3/4):135-137.

GiambelluCA, L.A. 1988. Descripción y crecimiento de un juvenil de Acanthochelys pallidipectoris (Freiberg, 1945). Boletín de la Asociación Herpetológica Argentina 4(2-3):6-7.

Giraudo, A.R. 1996. Geographic distribution, Acanthochelys pallidipectoris. Herpetological Review 27(4):210.

GonZales,L.,MuÑOZ,A., AND CoRTEZ,E. 2006. Primer reporte sobre la 
herpetofauna de la Reserva Natural "El Corbalán”, Tarija, Bolivia. Kempffiana 1:72-94.

Horne, B.D. 1993. Courthship behavior and oviposition of captive Acanthochelys pallidipectoris Freiberg. Herpetological Review 24(1):25.

Iverson, J.B. 1986. A Checklist with Distribution Maps of the Turtles of the World. Richmond, Privately printed, $283 \mathrm{pp}$.

Iverson, J.B. 1992. A Revised Checklist with Distribution Maps of the Turtles of the World. Richmond, Indiana: Privately printed, $393 \mathrm{pp}$.

LaVILla, E.O., Cruz, F.B., AND Scrocchi, G.J. 1995. Amphibiens et reptiles de laStation Biologique "LosColorados"dans la provincede Salta, Argentine. Revue Française d'Aquariologie 22(1-2):51-58.

McBee, K., Bickham, J.W., Rhodin, A.G.J., ANd Mittermeier, R.A. 1985. Karyotypic variation in the genus Platemys (Testudines: Pleurodira). Copeia 1985(2):445-449.

MERTENS, R. 1954. Bemerkenswerte Schildkröten aus Süd- und Zentralamerika. Die Aquarien und Terrarienzeitschrift 7(9):234-242.

MÉTRAILLER, S. 2008. Première reproduction en captivité de la Platémyde à éperons Acanthochelys pallidipectoris (Freiberg, 1945). Manouria 11(41):22-25.

Ministerio de Medio Ambiente y Agua. 2009. Libro Rojo de la Fauna Silvestre de Vertebrados de Bolivia. La Paz, Bolivia: Ministerio de Medio Ambiente y Agua, 571 pp.

Monguillot, J.C. and Fabius, S. 1993. Contribución al conocimiento de Platemys pallidipectoris Freiberg (Reptilia: Chelidae). Boletín de la Sociedad Zoológica del Uruguay 2(8):198-203.

Paszko, L. And Hernando, A. 2005. Datos preliminares sobre la biología y densidad relativa de Acanthochelys pallidipectoris (Chelonia: Chelidae) en el Parque Nacional Chaco (Chaco, Argentina). Universidad Nacional del Nordeste, Comunicaciones Científicas y Tecnológicas, B-066.

Picoloti, E. 2010. El monocultivo de soja está aniquilando al bosque nativo. Coordinación de Prensa y Difusión de Secretaría de Ambiente y Desarrollo Sustentable de la Nación. www.ambiente.gov. ar $/$ ?idarticulo $=5320$.

PIÑA,C.I.ANDLARRIERA,A.2001.Acanthochelys pallidipectoris(Chaco sideneck turtle). Herpetological Review 32(2):116.

RHodin, A.G.J. 1985. Status and taxonomic relationships of South American chelid turtles. American Philosophical Society Grantee's Reports 1984:41, 291-293.

Rhodin, A.G.J., Métrailler, S., VinKe, T., VinKe, S., ARTnER, H., AND MitTERMEIER, R.A. 2009. Acanthochelys macrocephala (Rhodin, Mittermeier, and McMorris 1984) - big-headed Pantanal swamp turtle,Pantanal swamp turtle. In: Rhodin,A.G.J., Pritchard,P.C.H., van Dijk, P.P., Saumure, R.A., Buhlmann, K.A., Iverson, J.B., and Mittermeier, R.A. (Eds.). Conservation Biology of Freshwater Turtles and Tortoises: A Compilation Project of the IUCN/SSC Tortoise and Freshwater Turtle Specialist Group. Chelonian Research Monographs No.5,pp.040.1-040.8, doi:10.3854/crm5.040. macrocephala.v1.2009, http://www.iucn-tftsg.org/cbftt/.

RICHARD, E. 1991. Oviposition of Acanthochelys pallidipectoris (Freiberg) in captivity (Chelonii: Chelidae).Bulletin of the Maryland Herpetological Society 27(2):107-109.

RICHARD, E. 1994. Sobre el status biogeográfico de las tortugas dulceacuícolas (Chelonii: Chelidae) de la provincia de Mendoza,
Argentina. Anales I Congres Argentina de Limnología, Tankay 1:287-291.

RichARD, E. 1998. Tortugas de las regiones áridas de Argentina. Contribución al conocimiento de las tortugas de las regiones áridas de Argentina (Chelidae y Testudinidae) con especial referencia a los aspectos ecoetológicos,comerciales y antropológicos de las especies del complejo chilensis (Chelonoidis chilensis y C.donosobarrosi) en la provincia de Mendoza. Doctoral Thesis, Universidad Nacional de Cuyo, Argentina.

RichARD, E. 1999. Tortugas de las Regiones Áridas de Argentina. Buenos Aires: LOLA, 200 pp.

RICHARD,E.2010.Actualización del estatus de conservación de tortugas de Argentina y Bolivia. Report to IUCN Tortoise and Freshwater Turtle Specialist Group and Asociación Herpetológica Argentina. Unpublished report, $22 \mathrm{pp}$.

RichARD,E. ANDBERTONATTI,Y.C. 1998.LibroRojo,numero60:Tortuga de Pantano. FVSA Vida Silvestre, Buenos Aires 62:21-22.

SAPORITI, E.J. 1943. Nuevo hallazgo de la tortuga acuática Platemys spixii D y B. Amplicación de su ditribución geográfica. Revista Argentina de Zoogeografía 3:73-74.

Scrocchi, G.J. AND GIRAUdo, A.R. 2001. Reptiles de la Reserva El Bagual.In:DiGiacomo,A.G.and Krapovickas, S.F.(Eds.).Historia Natural y Paisaje de la Reserva El Bagual, Formosa, Argentina. Inventario de la Fauna de Vertebrados y de la Flora Vascular de un Área del Chaco Húmedo. Temas de Naturaleza y Conservación, Vol.4.Buenos Aires: Aves Argentinas and Asociación Ornitológica del Plata, pp. 157-198.

VinKe, T. AND VINKE, S. 2001. The turtle and tortoise fauna of the central Chaco of Paraguay. Radiata 10(3):3-19.

VinKe, T. AND Vinke, S. 2008. Die Pantanal-Plattschildkröte, Acanthochelys macrocephala, erobert den Dornbuschtrockenwald. Schildkröten im Fokus 5(1):22-31.

VINKE, T. AND VINKE, S. 2009. Chelonoidis carbonaria - Red-Footed Tortoises in the Gran Chaco-adaptation to extreme habitat.Reptilia (GB) 67:16-21.

WALLER, T. 1988. Notas sobre la distribución de Acanthochelys spixii (D. y B., 1835) y Acanthochelys pallidipectoris (Freiberg, 1945) en la Argentina (Testudines: Chelidae). Amphibia y Reptilia (Conservación) 1(5):93-98.

ZARCO,A.ANDQUIROGA,V.2008.Nuevoregistroparala tortugaacuática chaqueña Acanthochelys pallidipectoris (Freiberg, 1945) en el "Impenetrable" de la Provincia del Chaco, Argentina. - APRONA Boletín Científico 40:33-35.

\section{Citation Format for this Account:}

Vinke, T., Vinke, S., Richard, E., Cabrera, M.R., Paszko, L., Marano, P., and Métrailler, S. 2011. Acanthochelys pallidipectoris (Freiberg 1945) - Chaco Side-Necked Turtle. In: Rhodin,A.G.J., Pritchard,P.C.H., van Dijk,P.P., Saumure, R.A., Buhlmann, K.A., Iverson, J.B., and Mittermeier, R.A. (Eds.). Conservation Biology of Freshwater Turtles and Tortoises: A Compilation Project of the IUCN/SSC Tortoise and Freshwater Turtle Specialist Group.Chelonian Research Monographs No. 5, pp.065.1-065.7,doi:10.3854/crm.5.065.pallidipectoris.v1.2011, http://www.iucn-tftsg.org/cbftt/. 